\title{
PENGARUH KUALITAS PELAYANAN TERHADAP KEPUASAN PELANGGAN KRL COMMUTERLINE DI KEBAYORAN LAMA
}

\author{
Lucy Nancy \\ mamaolgalucy@yahoo.co.id
}

Jurusan Manajemen, Fakultas Ekonomi, Universitas Satya Negara Indonesia Jalan Arteri Pondok Indah No.11 Jakarta Selatan

\begin{abstract}
Singer study aims to determine how the Effect QUALITY review Service Customer Satisfaction KRL Commuterline in Kebayoran Station. Population Research hearts Singer Was All users Train Station Commuterline in Kebayoran Lama. Searching Google Articles 45 Passengers taking samples, sampling methods accidental WITH collecting data using questionnaires, while the measurement of the variables which are used scale you Likkert WITH five stretches.

Methods Data Testing done is test the reliability and validation. Methods of Data Analysis Performed: Correlation analysis, Classical Assumption Test, Multiple Linear Regression Analysis, $t$ test and $f$ test and coefficient of determination (R2). Research shows that physical evidence, Responsiveness and Assurance NOT have an influence KRL Customer Satisfaction Commuterline while reliability and empathy has influence KRL Commuterline Customer Satisfaction.
\end{abstract}

Keywords: Physical Evidence, Reliability, Responsiveness, Assurance, Empathy And Customer Satisfaction.

\section{PENDAHULUAN}

Berkembangnya perekonomian dan meningkatnya jumlah penduduk menyebabkan permintaan terhadap pelayanan jasa transportasi semakin meningkat tajam. Sistem perhubungan (transportasi) yang baik akan mendorong tumbuhnya ekonomi yang efisien dan berdaya saing. Transportasi secara umum terdiri dari transportasi darat, transportasi udara, dan transportasi laut, ketiga jenis transportasi ini memiliki peranan masing-masing.Salah satu jenis transportasi yang dapat dijadikan alternatif untuk mengatasi permasalahan kebutuhan transportasi masyarakat di atas adalah kereta api. Kereta api merupakan alat transportasi dengan banyak keunggulan seperti rendah polusi, bebas macet, bersifat massal, biaya lebih murah, dan juga waktu relatif lebih cepat. Kereta Api Listrik Commuter Line Jabodetabek atau disingkat KCJ adalah salah satu sarana transportasi strategis dijantung Ibukota Jakarta dan sekitarnya (Bogor-Depok-Tangerang-Bekasi). penggunaan jasa transportasi kereta api perlu dikembangkan dan mendapat perhatian khusus dari pemerintah, karena diharapkan jasa transportasi kereta api akan dapat menjadi pilihan utama bagi pengguna jasa transportasi darat di Indonesia. Peningkatan jumlah penumpang rata-rata $13.9 \%$ meningkat pesat dari tahun ke tahun, dari tahun 2011 jumlah penumpang 331,760 orang/hari sampai tahun 2015 saja peningkatan jumlah penumpang tercatat mencapai 914,840 orang/hari. Seperti ynag terlihat pada table 1 . 


\section{Tabel 1}

Peningkatan Jumlah Penumpang KRL per hari tahun 2011-2015

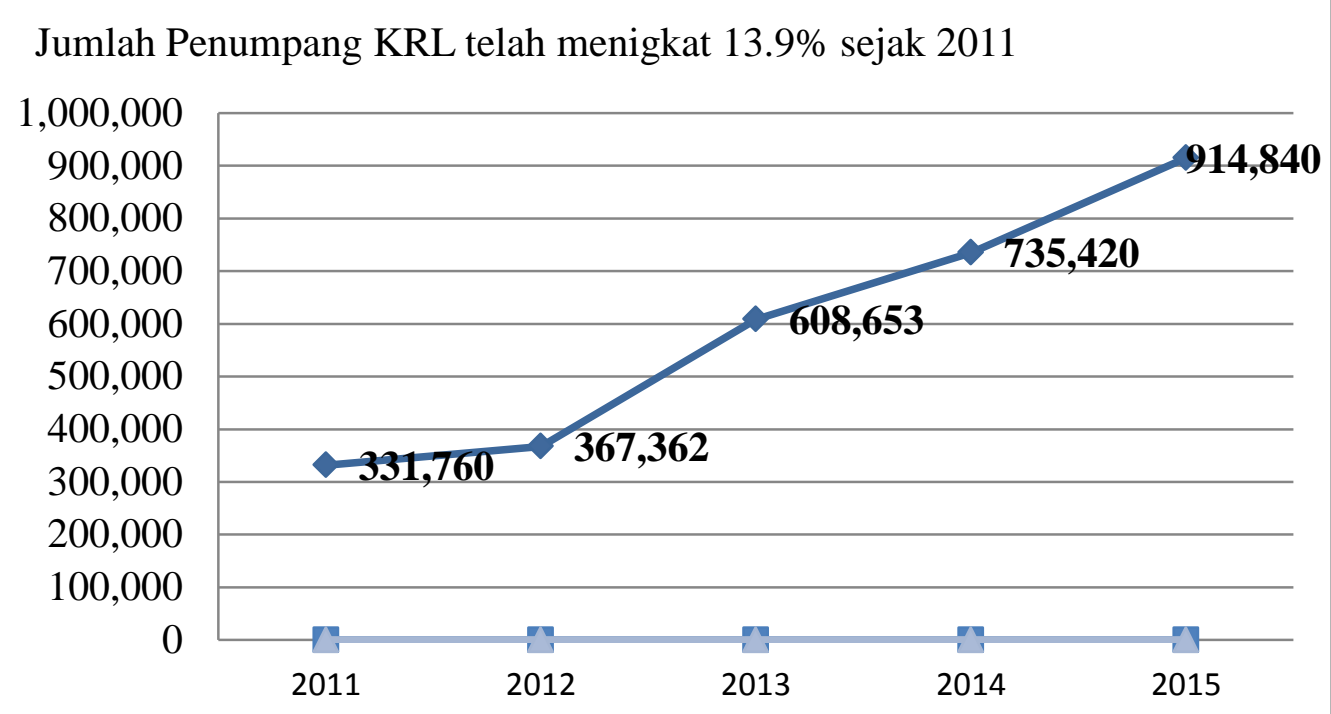

Sumber: PT. KAI Cabang Jakarta 2015

Kondisi ini menunjukkan bahwa transportasi yang masif merupakan kebutuhan yang mendesak, karena tumbuh kembangnya sektor transportasi yang baik akan memberikan andil yang cukup besar bagi perkembangan di sektor lain seperti perdagangan, perindustrian, keuangan, dan jasa-jasa. organisasi dalam kehidupan ekonomi,politik, sosial dan budaya, dan lain sebagainya. Keseluruhan tuntutan tersebut di atas dimanifestasikan dengan tidak hanya ketersediaan pelayanan secara kuantitas, namun juga ketersediaan dari kualitas pelayanan itu sendiri dikarenakan ketersediaan secara kuantitas belum tentu menjamin peningkatan derajat hidup masyarakat tanpa diikuti dengan tatakelola kualitas penyelenggaraan pelayanan yang ada.

Untuk bisa menjadi pilihan utama dalam jasa layanan transportasi maka jasa layanan transportasi kereta api harus mampu memberikan kepuasan yang maksimun terhadap penggunanya. Dalam dunia bisnis yang semakin kompetitif kepuasan konsumen merupakan kunci dalam menciptakan loyalitas konsumen. Layanan jasa transportasi kereta api yang mampu memberikan kepuasan terhadap penggunanya maka pengguna dari kendaraan pribadi dan kendaraan lain akan beralih ke jasa transportasi kereta api dan hal ini akan berkontribusi pada pengurangan kemacetan. Salah satu strategi yang ditempuh selain membenahi infrastruktur adalah membenahi managemen perjalanan dengan menggabungkan perjalanan kelas ekpress AC yang semula hanya berhenti pada stasiun-stasiun tertentu dan beroperasi pada jam-jam tertentu dengan kelas ekonomi AC yang berhenti di semua stasiun kereta api, sedang pada kelas ekonomi secara perlahan akan dihapuskan. Dengan demikian KRL Jabodetabek menerapkan sistem baru yang disebut dengan Commuter Line Single Operation yang beroperasi secara terus menerus dan berhenti pada semua stasiun kereta api yang mulai beroperasi terhitung sejak 2 Juli 2011.

PT. KAI Commuter Jabodetabek merencanakan penambahan armada guna mengejar target program pemerintah yang merencanakan agar KRL Jabodetabek mampu mengangkut 1.2 juta penumpang per hari. Program pengadaan armada akan dilakukan setiap tahun hingga akhir tahun 2019 dimana jumlah armada diharapkan dapat mengakomodir target 1.2 juta 
penumpang per hari. Total armada KRL yang telah beroprasi sebanyak 666 unit sudah melayani 700-900 ribu penumpang per hari. Berikut data penambahan armada tahun 20112015.

Tabel .2

Penambahan Armada KRL Commuter Line Jabodetabek 2011 -2015.

\begin{tabular}{|c|c|c|}
\hline Tahun & $\begin{array}{l}\text { Jumlah } \\
\text { KRL }\end{array}$ & Keterangan \\
\hline $\begin{array}{l}2011 \\
2012 \\
2013 \\
2014 \\
2015\end{array}$ & $\begin{array}{l}100 \\
90 \\
180 \\
176 \\
120\end{array}$ & $\begin{array}{l}\text { KRL Seri JR } 203 \text { Tokyo } \\
\text { Metro seri } 6000 \\
\text { KRL Seri JR } 203 \\
\text { KRL Seri } 205 \\
\text { KRL Seri JR } 205 \\
\text { KRL Seri JR } 205\end{array}$ \\
\hline Jumlah & 666 & \\
\hline
\end{tabular}

Sebagai jenis layanan transportasi yang banyak diminati masyarakat, masih banyak kelemahan dari pelayanan KRL diantaranya adalah: (1) Jumlah penumpang yang melebihi kapasitas sehingga membuat penumpang merasa tidak nyaman ; (2) Gangguan perjalanan kereta seperti kereta anjlok, kereta mogok, gangguan persinyalan, gangguan wessel (pemindah jalur), gangguan listrik, serta tidak tepatnya jadwal keberangkatan kereta menjadi 'makanan' sehari-hari para penggunanya. (3) Sering terjadi kecelakaan kereta api baik yang disebabkan oleh human error maupun kesalahan teknis sehingga belum bisa memberikan jasa pelayanan yang aman. Keluhan, hujatan dan kritik-kritik pedas masih sering terlontar dari masyarakat sebagai pengguna jasa transportasi KRL, Di satu pihak, manajemen PT KCJ mungkin berupaya terus menerus untuk meningkatkan pelayanan, seperti misalnya kebersihan didalam kereta, memperbaiki peron-peron di stasiun, kontinuitas informasi keberadaan rangkaian, hingga peremejaan gerbong

Menurut Fandy Tjiptono, (2012:74) Kualitas Pelayanan mencerminkan perbandingan antara tingkat layanan yang disampaikan perusahaan dibandingkan ekspektasi pelanggan. Kesimpulannya, kualitas pelayanan adalah perbandingan antara harapan pelanggan terhadap perusahaan dalam pemenuhan kebutuhan dan keinginannya dengan persepsi pelanggan terhadap kinerja layanan yang diterimanya seperti ketepatan dan cara penyampaiannya. Dalam menentukan kualitas layanan, terdapat lima dimensi sebagaimana telah dikemukakan oleh Parasuraman et.al. (1998) dalam Tjiptono (2014:282) oleh yaitu dimensi Tangibles, Reliability, Responsiveness, Assurance dan Emphaty. 
Menurut (Kotler, 2009:138) Kepuasan adalah perasaan senang atau kecewa seseorang yang timbul karena membandingkan kinerja yang dipersepsikan terhadap ekspektasi atau harapan mereka. Terciptanya kepuasan pelanggan dapat memberikan beberapa manfaat antara perusahaan dan atribut-atribut yang bersangkutan. Sehingga tercipta hubungan dengan pelanggan menjadi harmonis memberikan dasar yang baik bagi pembelian ulang dan terciptanya loyalitas pelanggan dan membentuk suatu rekomendasi dari mulut ke mulut (Tjiptono, 2011:24).

Maka berdasarkan penjelasan diatas yang menunjukan ada perbedaan secara teoritis dan fenomena yang terjadi dan diperkuat dengan penelitian-penelitian sebelumnya yang menunjukan hasil yang berbeda juga, penulis tertarik untuk melakukan penelitian dengan judul : "ANALISIS PENGARUH KUALITAS PELAYANAN TERHADAP KEPUASAN PELANGGAN KRL COMMUTERLINE DI STASIUN KEBAYORAN LAMA.

\section{Perumusan Masalah} yaitu :

Berdasarkan uraian latar belakang diatas, maka dapat disimpulkan perumusan masalah

1. Apakah Variabel Tangibles (Bukti Fisik) berpengaruh terhadap Kepuasan Pelanggan KRL Commuterline di Stasiun Kebayoran Lama?

2. Apakah Variabel Reliability (Kehandalan) berpengaruh terhadap Kepuasan Pelanggan KRL Commuterline di Stasiun Kebayoran Lama?

3. Apakah Variabel Responsiveness (Daya Tanggap) berpengaruh terhadap Kepuasan Pelanggan KRL Commuterline di Stasiun Kebayoran Lama?

4. Apakah Variabel Assurance (Jaminan) berpengaruh terhadap Kepuasan Pelanggan KRL Commuterline di Stasiun Kebayoran Lama?

5. Apakah Variabel Empathy (Empati) berpengaruh terhadap Kepuasan Pelanggan KRL Commuterline di Stasiun Kebayoran Lama?

6. Apakah Variabel Tangibles, Realibility, Responsiveness, Assurance, dan Empathy berpengaruh terhadap Kepuasan Pelanggan KRL Commuterline di Stasiun Kebayoran Lama?

\section{KERANGKA PEMIKIRAN TEORITIS}

\section{Kualitas Layanan}

Menurut Parasurama, et. al (1988) dalam Tjiptono (2014:268) mendefinisikan Kualitas jasa adalah "merupakan tingkat keunggulan yang di harapkan dan pengendalian atas keunggulan untuk memenuhi keinginan pelanggansebagai ukuran seberapa bagus tingkat layanan yang diberikan mampu sesuai dengan ekspektasi pelanggan”.

\section{Dimensi Kualitas Layanan}

Parasuraman, Zeithaml dan Berry (1988) dalam Tjiptono (2012:174-175), menyebutkan ada lima dimensi dalam Kualitas Layanan tersebut, yaitu:

1) Bukti Fisik (Tangibles)

Yaitu berkenaan dengan penampilan fisik fasilitas layanan, peralatan/perlengkapan, sumber daya manusia dan materi komunikasi perusahaan.

2) Keandalan (Reliability)

Yaitu kerkaitan dengan kemampuan perusahaan untuk menyampaikan layanan yang dijanjikan secara akurat sejak pertama kali.

3)Daya Tanggap (Responsiveness) 
Yaitu berkenaan dengan kesediaan dan kemampuan penyedia layanan untuk membantu para pelanggan dan merespon permintaan mereka dengan segera.

\section{4) Jaminan (Assurance)}

Yaitu berkenaan dengan pengetahuan dan kesopanan karyawan serta kemampuan mereka dalam menumbuhkan rasa percaya (trust) dan keyakinan pelanggan (confidence).

\section{5) Empati (Empathy)}

Yaitu bahwa perusahaan memahami masalah para pelanggannya dan bertindak demi kepentingan pelanggan serta memberikan perhatian personal kepada para pelanggan dan memiliki jam operasi yang nyaman.

\section{Indikator Kualitas Layanan}

Indikator yang mencirikan Kualitas Layanan yang digunakan dalam penelitian ini, yaitu dalam Tjiptono (2012:174-175):

1) penampilan fisik fasilitas layanan, peralatan/perlengkapan, sumber daya manusia dan materi komunikasi perusahaan.

2) Memberikan dan menyampaikan layanan sesuai yang dijanjikan secara akurat.

3) kemampuan penyedia layanan untuk membantu dan merespon permintaan.

4) Pengetahuan, keramahan, kesopanan dan kinerja yang baik.

5) Memberikan perhatian dan memahami keinginan pelanggan.

\section{Kepuasan Pelanggan}

\section{Definisi Kepuasan Pelanggan}

Menurut Kotler dan Keller (2000) dalam Nurul (2011:178) mendefinisikan Kepuasan Pelanggan adalah "tingkat perasaan seseorang setelah membandingkan kinerja atau hasil yang dirasakan dengan yang diharapkan"

\section{Tahap-Tahap Kepuasan Pelanggan}

Wilkie dikutip oleh Conny, (2014:25-27) membagi kepuasan pelanggan ke dalam lima tahapan yaitu:

\section{1) Pengharapan (Expectations)}

Sebelum melakukan pembelian terhadap suatu produk atau jasa, dalam benak konsumen sudah terdapat suatu ekspektasi bahwa jika nanti dia membeli produk atau jasa ini maka dia mengharapkan akan menerima suatu tingkatan nilai yang didefinisikan oleh konsumen itusendiri.

\section{2) Kinerja (Performance)}

Setelah membeli maka kemudian konsumen merasakan atau mengalami suatu situasi atau kondisi yang disebabkan oleh kinerja dari produk atau jasa yang telah dibelinya.

\section{3) Membandingkan (Comparison)}

Di tahap ini konsumen kemudian mulai membandingkan antara harapan yang dia inginkan sebelum membeli produk atau jasa tersebut dengan perasaan atau pengalaman yang diterima dari kinerja produk atau jasa tersebut.

\section{4) Konfirmasi/Diskonfirmasi (Confirmation/Disconfirmation)}

Di tahap ini konsumen memperoleh suatu hasil dari perbandingan antara harapan konsumen dan kinerja produk atau jasa yang dibelinya. Apabila kinerja produk atau jasa tersebut sama dengan yang diharapkan, maka konsumen mengalami confirmation of expectations.

\section{5) Ketidaksesuaian (Discrepancy)}


Pada tahap ini konsumen akan mulai mengalami ketidakpuasan karena kinerja dari produk atau jasa tersebut tidak sesuai atau tidak cocok dengan apa yang diharapkan. Hal ini akan mendorong pada pengambilan keputusan untuk berpindah pada produk atau jasa pesaing atau tidak.

\section{Elemen Pengukuran Kepuasan Pelanggan}

Dalam Tjiptono (2014:368-369) mengemukakan cara mengukur kepuasan pelanggan terdapat kesamaan paling tidak dalam enam konsep inti mengenai obyek pengukuran:

1) Kepuasan Pelanggan Keseluruhan (Overall Customer Statisfaction)

adalah langsung menanyakan kepada pelanggan seberapa puas mereka dengan produk atau jasa secara keseluruhan.

2) Konfirmasi Harapan (Confirmation of expectations)

Kesesuaian/ketidaksesuaian antara harapan pelanggan dengan kinerja aktual perusahaan pada sejumlah atribut atau dimensi penting.

3) Nilai Beli Ulang (Repurchase Intention)

Kepuasan Pelanggan diukur secara behavioral apakah pelanggan akan berbelanja atau menggunakan jasa perusahaan lagi.

4) Kesediaan Untuk Merekondasi (willingness to Recommend)

Kesediaan pelanggan untuk merekomendasikan produk kepada teman atau keluarganya menjadi ukuran yang penting untuk dianalisis dan ditindaklanjuti.

5) Ketidakpuasan pelanggan (Customer Disstatisfaction)

Beberapa macam aspek yang sering ditelaah guna mengetahui ketidakpuasan pelanggan, meliputi: complain, pengembalian produk, biaya garansi dll.

\section{Gambar 1}

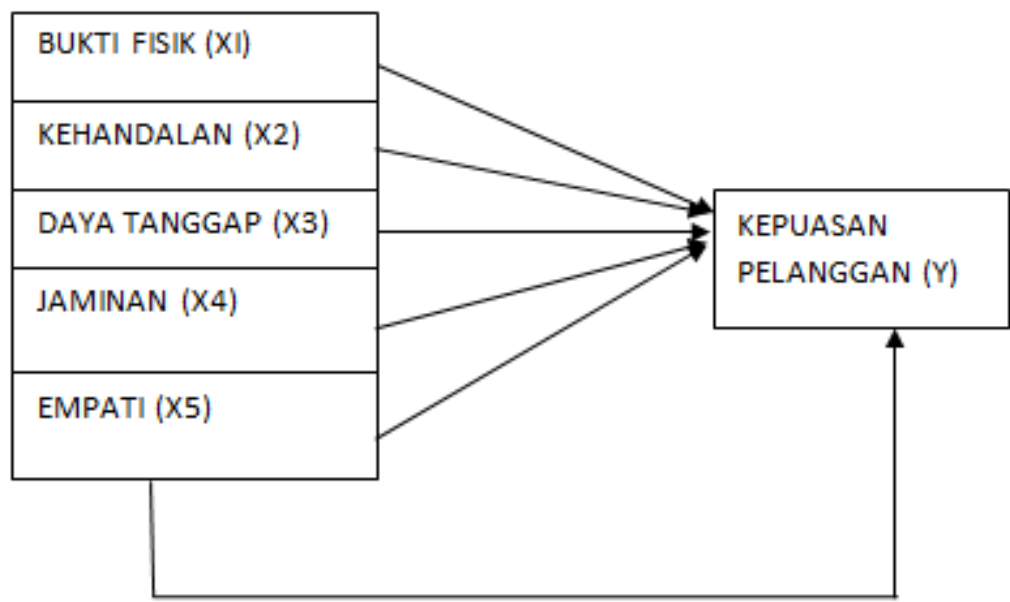

Sumber: diolah oleh penulis, 2016

\section{METODE}

\section{Waktu dan tempat peneliti}

Penelitian ini dilaksanakan di PT KAI Commuterline Jabodetabek cabang Kebayoran Lama. Pemilihan lokasi untuk penelitian ini dilakukan secara sengaja (purposive). Penelitian ini dilaksanakan selama 2 bulan, yaitu mulai pada bulan April sampai Mei 2016. 


\section{Desain Penelitian}

Dalam penelitian ini desain penelitian yang digunakan yaitu Penelitian Kausal, yaitu penelitian yang bertujuan untuk mengetahui pengaruh antara satu atau lebih variabel independen terhadap variabel dependen.

\section{Populasi dan Sampel}

Populasi dalam penelitian ini adalah seluruh pengguna kereta api Commuterline di stasiun Kebayoran Lama.Metode pemilihan sampel yang di gunakan yaitu metode Non Probability Sampling, populasi yang tak terhingga dimana semua populasi tidak memiliki peluang yang sama untuk menjadi responden dan pengambilan sampel didasarkan pada pertimbangan peneliti. Adapun teknik penentuan sampling dalam penelitian ini adalah teknik Sampling Aksidental yaitu siapa saja yang secara kebetulan bertemu dengan peneliti dapat digunakan sebagai sampel, bila dipandang orang yang kebetulan ditemui itu cocok sebagai sumber data. Pemilihan tersebut dilakukan setiap hari selama penelitian pada jam Operasi KRL Commuter Line di Kebayoran Lama.Sampel yang di gunakan sebanyak 45 responden

\section{Metode Pengujian Data}

\section{Uji Validitas}

Uji validitas bertujuan untuk mengukur data hasil dari penyebaran kuesioner apakah data yang didapat valid atau layak dijadikan untuk penelitian ini. Kritera dalam pengujian validitas ini adalah :

Jika $r_{\text {hitung }}>r_{\text {tabel }}$ maka valid

Jika $r_{\text {hitung }}<r_{\text {tabe }} l$ maka tidak valid

\section{Uji reliabilitas}

Uji reliabilitas bertujuan untuk mengetahui tingkat kehandalan dari suatu instrumen penelitian. Pengujian reliabilitas dilakukan setelah uji validitas dan yang diuji merupakan pertanyaan yang sudah valid. Kriteria dalam pengujian reliabilitas jika croanbach's alpa > 0,6 maka data reliabel atau handal.

\section{Transformasi Data Ordinal Ke Interval}

Setelah data yang di uji telah dinyatakan valid dan realibel, data tersebut dapat langsung digunakan untuk analisis atau pengolahan data selanjutnya yaitu regresi. Untuk melakukan pengolahan data regresi maka data yang dimiliki merupakan data interval. Trasformasi data ordinal yang dimiliki menjadi data interval dengan menggunakan rumus berikut:

$$
\mathrm{Ti}=50+10 \quad \frac{(\mathrm{Xi}-\pi)}{\alpha}
$$

\section{Keterangan:}

$\mathbf{T i}=$ Skor baku ( Data Interval)

$\mathbf{X i}=$ Skor mentah (Data Ordinal)

$\boldsymbol{\pi}=$ Rata - rata ( Mean)

$\boldsymbol{\alpha}=$ Standar Deviasi

\section{Metode Analisis data}

\section{Analisis deskriptif}

Metode analisis deskriptif merupakan metode yang digunakan untuk menganalisis data-data yang tersedia dan diolah sehingga diperoleh gambaran yang jelas mengenai fakta-fakta fenomena yang diteliti. 


\section{Analisis Korelasi}

Analisis korelasi digunakan untuk menguji keeratan hubungan antara dua variabel atau lebih.Koefisien korelasi sederhananya menunjukan seberapa besar hubungan yang terjadi antara variabel independen dengan variabel dependen.

3. Uji Asumsi Klasik
a.Uji normalitas
b.Uji multikolinieritas
c.Uji heteroskedastisitas
d.Uji autokorelasi

\section{Tahap-tahap pengujian hipotesa}
a.Analisa deskriptif
b.Analisa korelasi
c.Regresi linier berganda
d.Uji t
e.Uji $\mathrm{f}$
f.Determinasi $R^{2}$

\section{PEMBAHASAN}

\section{Profil Responden}

Gambaran umum mengenai responden yang menjadi subyek dalam penelitian ini ditunjukkan pada Tabel 4.2. Responden dalam penelitian ini adalah konsumen Commuterline di Kebayoran Lama yang sekurang-kurangnya telah datang 2 kali. Profil responden tersebut terdiri dari jenis kelamin, usia, pendidikan, tujuan dan pekerjaan. Secara umum, profil responden dapat dilaporkan bahwa jumlah konsumen laki-laki sebanyak 15 (33,33\%) dan perempuan sebanyak $30(66,66 \%)$ responden. Untuk usia antara 17-24 tahun sebanyak 15 $(33,33 \%)$, antara 25-34 tahun sebanyak $10(22,22 \%)$, antara 35-49 tahun sebanyak 10 $(22,22 \%)$, antara 50-64 tahun sebanyak 10 (22,22 \%), Untuk Responden melakukan tujuan : ketempat kerja sebanyak 15 (33,33\%), berbelanja 5 (11,11\%),ke sekolah 20 (44,44\%), Kunjungan keluarga 5 ( $11,11 \%)$,Untuk Responden yang mempunyai Pekerjaan: Pelajar sebanyak $25(55,55 \%)$, Pegawai swasta sebanyak 15 (33.33\%), pedagang $2(4,44 \%)$, tidak bekerja sebanyak 5 (11,11\%), Untuk Responden yang memiliki pendidikan: SLTA sebanyak 15 (33,33\%), untuk diploma 3 (6,66\%), untuk S1 2 (4,44\%), untuk S2 sebanyak $22(48,88 \%)$, untuk S3 sebanyak 3(6,66\%) lebih jelasnya dapat dilihat pada tabel berikut ini :

\section{Uji Reliabilitas}

Uji Reliabilitas variabel Bukti Fisik (X1)

Tabel 3

Reliability Statistics

\begin{tabular}{|l|l|l|}
\hline $\begin{array}{l}\text { Cronbach's } \\
\text { Alpha }\end{array}$ & $\begin{array}{l}\text { Cronbach's } \\
\text { Alpha Based } \\
\text { on } \\
\text { Standardized } \\
\text { Items }\end{array}$ & $\begin{array}{l}\text { Items of } \\
.976\end{array}$ \\
\hline .975 & .976 \\
\hline
\end{tabular}

Sumber : Output SPSS 
Berdasarkan Tabel diatas menunjukkan Cronbach's Alpha 0,973 $\geq 0,60$. Dapat disimpulkan bahwa pernyataan-pernyataan dalam variable Bukti Fisik, adalah reliable, artinya bahwa hasil pengukuran variabel Bukti Fisik adalah konsisten

Uji Reliabilitas variabel Kehandalan (X2)

Tabel 4

Reliability Statistics

\begin{tabular}{|l|l|ll|}
\hline $\begin{array}{l}\text { Cronbach's } \\
\text { Alpha }\end{array}$ & $\begin{array}{l}\text { Cronbach's } \\
\text { Alpha Based } \\
\text { on } \\
\text { Standardized } \\
\text { Items }\end{array}$ & \begin{tabular}{l} 
Items \\
\hline .960
\end{tabular} & \begin{tabular}{l} 
of \\
\hline
\end{tabular} \\
\hline
\end{tabular}

Sumber : Output SPSS

Berdasarkan Tabel diatas menunjukkan Cronbach's Alpha 0,973 $\geq 0,60$. Dapat disimpulkan bahwa pernyataan pernyataan dalam variabel Kehandalan adalah reliable, artinya bahwa hasil pengukuran variabel Kehandalan adalah konsisten.

Uji Reliabilitas Variabel Daya Tanggap (X3)

\section{Tabel 5}

Reliability Statistics

\begin{tabular}{|c|c|c|}
\hline $\begin{array}{c}\text { Cronbach's } \\
\text { Alpha }\end{array}$ & $\begin{array}{c}\text { Cronbach's } \\
\text { Alpha Based } \\
\text { on } \\
\text { Standardized } \\
\text { Items }\end{array}$ & $\begin{array}{c}\text { Items of } \\
\text { Items }\end{array}$ \\
\hline .978 & .979 & 5 \\
\hline
\end{tabular}

Sumber : OutputSPSS

Berdasarkan Tabel diatas menunjukkan Cronbach's Alpha 0,978 $\geq 0,60$. Dapat disimpulkan bahwa pernyataan-pernyataan dalam variabel Daya Tanggap adalah reliable, artinya bahwa hasil pengukuran variabel Daya Tanggap adalah konsisten.

Uji Reliabilitas Variabel Jaminan (X4)

Tabel 6

Reliability Statistics

\begin{tabular}{|c|c|c|}
\hline $\begin{array}{l}\text { Cronbach's } \\
\text { Alpha }\end{array}$ & $\begin{array}{l}\text { Cronbach's } \\
\text { Alpha Based } \\
\text { on } \\
\text { Standardized } \\
\text { Items }\end{array}$ & $\begin{array}{ll}\mathrm{N} & \text { of } \\
\text { Items } & \end{array}$ \\
\hline .976 & .977 & 5 \\
\hline
\end{tabular}

Sumber : OutputSPSS 
Berdasarkan Tabel diatas menunjukkan Cronbach's Alpha 0,978 $\geq 0,60$. Dapat disimpulkan bahwa pernyataan-pernyataan dalam variabel Jaminan adalah reliable, artinya bahwa hasil pengukuran variabel Jaminan adalah konsisten

Uji Reliabilitas Variabel Empati (X5)

Tabel 7

Reliability Statistics

\begin{tabular}{|c|c|c|}
\hline $\begin{array}{l}\text { Cronbach's } \\
\text { Alpha }\end{array}$ & $\begin{array}{l}\text { Cronbach's } \\
\text { Alpha Based } \\
\text { on } \\
\text { Standardized } \\
\text { Items }\end{array}$ & $\begin{array}{ll}\mathrm{N} & \text { of } \\
\text { Items } & \end{array}$ \\
\hline .972 & .973 & 5 \\
\hline
\end{tabular}

Sumber : OutputSPSS

Berdasarkan Tabel diatas menunjukkan Cronbach's Alpha 0, 975 $\geq 0,60$. Dapat disimpulkan bahwa pernyataan-pernyataan dalam variabel Empati adalah reliable, artinya bahwa hasil pengukuran variabel Empati adalah konsisten

Uji Reliabilitas Variabel Kepuasan pelanggan KRL Commuterline (Y)

Tabel 8

Reliability Statistics

\begin{tabular}{|c|c|c|}
\hline $\begin{array}{l}\text { Cronbach's } \\
\text { Alpha }\end{array}$ & $\begin{array}{l}\text { Cronbach's } \\
\text { Alpha Based } \\
\text { on } \\
\text { Standardized } \\
\text { Items }\end{array}$ & $\begin{array}{ll}\mathrm{N} & \text { of } \\
\text { Items } & \end{array}$ \\
\hline .964 & .964 & 4 \\
\hline
\end{tabular}

Sumber : Output SPSS

Berdasarkan Tabel diatas menunjukkan Cronbach's Alpha 0,964 $\geq 0,60$. Dapat disimpulkan bahwa pernyataan-pernyataan dalam variabel Kepuasan pelanggan KRL Commuterline adalah reliable, artinya bahwa hasil pengukuran variabel Kepuasan Pelanggan KRL Commuterline adalah konsisten

\section{Uji Validitas}

Pengujian validitas data dimaksudkan adalah untuk mengetahui apakah data yang terkumpul dari responden telah memenuhi syarat sebagai alat ukur yang tepat.Hal ini menunjukkan terjadinya internal konsistensi jawaban atas instrumen-instrumen kuesioner. Kriteria yang dipakai adalah rhitung dibandingkan dengan rtabel Apabila r-hitung > rtabel dapat disimpulkan instrumen tersebut dianggap valid. Uji validitas ini dilakukan dengan 
membandingkan nilai $r$-hitung dengan rtabel untuk $\mathrm{df}=\mathrm{n}-\mathrm{k}-1$. Dalam penelitian ini $\mathrm{df}=45-5$ - 1 atau df = 39 dengan $\alpha$ 0,05 didapat rtabel sebesar 0,206. Jika r-hitung (per item) lebih besar dari rtabel berarti pernyataan tersebut dikatakan valid. Hasil uji validitas untuk r-hitung (per item) dapat dilihat dalam hasil output SPSS pada pada kolom Correctedd Item Total seperti yang disajikan sebagai beriikut:

Uji Validitas Variabel Bukti Fisik (X1)

Tabel 9

Hasil Uji Validitas Bukti Fisik

\begin{tabular}{|l|l|l|l|}
\hline Item & $\begin{array}{l}\text { Corrected } \\
\text { Item-Total } \\
\text { Correlation }\end{array}$ & r-tabel & Keterangan \\
\hline PB1 & .930 &, 206 & Valid \\
PB2 & .962 &, 206 & Valid \\
PB3 & .963 &, 206 & Valid \\
PB4 & .852 &, 206 & Valid \\
PB5 & .937 &, 206 & Valid \\
\hline
\end{tabular}

Sumber Data : Output SPSS

Berdasarkan tabel di atas pada kolom Correctedd Item Total Statistic (r-hitung) untuk masingmasing item atau butir pernyataan nilainya lebih besar dari rtabel 0,206, sehingga dapat disimpukan bahwa 5 pernyataan untuk variabel Bukti Fisik adalah valid

Uji Validitas Variabel Kehandalan (X2)

Tabel 10

Hasil Uji Validitas Kehandalan

\begin{tabular}{|l|l|l|l|}
\hline Item & $\begin{array}{l}\text { Corrected } \\
\text { Item-Total } \\
\text { Correlation }\end{array}$ & r- tabel & Keterangan \\
\hline PK1 & .930 &, 206 & Valid \\
PK2 & .962 &, 206 & Valid \\
PK3 & .963 &, 206 & Valid \\
PK4 & .852 &, 206 & Valid \\
PK5 & .937 &, 206 & Valid \\
\hline
\end{tabular}

Sumber Data : Output SPSS

Berdasarkan tabel di atas pada kolom Correctedd Item Total Statistic (r-hitung) untuk masingmasing item atau butir pernyataan nilainya lebih besar dari rtabel 0,206, sehingga dapat disimpukan bahwa 5 pernyataan untuk variabel Kehandalan adalah valid. 
Uji Validitas Variabel Daya Tanggap (X3)

Tabel 11

Hasil Uji Validitas Daya Tanggap

\begin{tabular}{|l|l|l|l|}
\hline & $\begin{array}{l}\text { Corrected } \\
\text { Item-Total } \\
\text { Correlation }\end{array}$ & r- tabel & Keterangan \\
\hline Item & .940 &, 206 & Valid \\
PD2 & .939 &, 206 & Valid \\
PD3 & .951 &, 206 & Valid \\
PD4 & .842 &, 206 & Valid \\
PD5 & .923 &, 206 & Valid \\
\hline
\end{tabular}

Sumber Data : Output SPSS

Berdasarkan tabel di atas pada kolom Correctedd Item Total Statistic (r-hitung) untuk masingmasing item atau butir pernyataan nilainya lebih besar dari rtabel 0,206, sehingga dapat disimpukan bahwa 5 pernyataan untuk variabel Daya Tanggap adalah valid

Uji Validitas Variabel Jaminan (X4)

Tabel 12

Hasil Uji Validitas Jaminan

\begin{tabular}{|l|l|l|l|}
\hline Item & $\begin{array}{l}\text { Corrected } \\
\text { Item-Total } \\
\text { Correlation }\end{array}$ & r-tabel & Keterangan \\
\hline PJ1 & .948 &, 206 & Valid \\
PJ2 & .939 &, 206 & Valid \\
PJ3 & .972 &, 206 & Valid \\
PJ4 & .925 &, 206 & Valid \\
PJ5 & .879 &, 206 & Valid \\
\hline
\end{tabular}

Sumber Data : Output SPSS

Berdasarkan tabel di atas pada kolom Correctedd Item Total Statistic (r-hitung) untuk masingmasing item atau butir pernyataan nilainya lebih besar dari rtabel 0,206, sehingga dapat disimpukan bahwa 5 pernyataan untuk variabel Jaminan adalah valid.

Uji Validitas Variabel Empati (X5)

Tabel 13

Hasil Uji Validitas Jaminan

\begin{tabular}{|l|l|l|l|}
\hline Item & $\begin{array}{l}\text { Corrected } \\
\text { Item-Total } \\
\text { Correlation }\end{array}$ & r- tabel & Keterangan \\
\hline PE1 & .935 &, 206 & Valid \\
PE2 & .912 &, 206 & Valid \\
PE3 & .923 &, 206 & Valid \\
PE4 & .915 &, 206 & Valid \\
PE5 & .922 &, 206 & Valid \\
\hline
\end{tabular}

Sumber Data : Output SPSS 
Berdasarkan tabel di atas pada kolom Correctedd Item Total Statistic (r-hitung) untuk masingmasing item atau butir pernyataan nilainya lebih besar dari rtabel 0,206, sehingga dapat disimpukan bahwa 5 pernyataan untuk variabel Empati adalah valid

\section{Analisis Data}

\section{Analisis Korelasi}

Untuk menganalisa korelasi antara variabel Bukti fisik, Kehandalan, Daya tanggap, Jaminan, Empati terhadap Kepuasan Pelanggan dapat dilihat dari hasil output SPSS pada tabel berikut :

Tabel 14

\begin{tabular}{|c|c|c|c|c|c|c|c|}
\hline \multicolumn{8}{|c|}{ Correlations } \\
\hline & & $\mathrm{X} 1$ & $\mathrm{X} 2$ & $\mathrm{X} 3$ & $\mathrm{X} 4$ & $\mathrm{X} 5$ & $\mathrm{Y}$ \\
\hline \multirow[t]{3}{*}{$\mathrm{X} 1$} & $\begin{array}{l}\text { Pearson } \\
\text { Correlation }\end{array}$ & 1 & & & & & \\
\hline & Sig. (2-tailed) & & .000 & .000 & .000 & .000 & .000 \\
\hline & $\mathrm{N}$ & 45 & 45 & 45 & 45 & 45 & 45 \\
\hline \multirow[t]{3}{*}{$\mathrm{X} 2$} & $\begin{array}{l}\text { Pearson } \\
\text { Correlation }\end{array}$ & $.979^{* *}$ & 1 & $.966^{* *}$ & $.972^{* *}$ & $.972^{* *}$ & $.980^{\circ}$ \\
\hline & Sig. (2-tailed) & .000 & & .000 & .000 & .000 & .000 \\
\hline & $\mathrm{N}$ & 45 & 45 & 45 & 45 & 45 & 45 \\
\hline \multirow[t]{3}{*}{$\mathrm{X} 3$} & $\begin{array}{l}\text { Pearson } \\
\text { Correlation }\end{array}$ & $.969^{* *}$ & $.966^{* *}$ & 1 & $.986^{* 4}$ & $.971^{* *}$ & $.960^{4 *}$ \\
\hline & Sig. (2-tailed) & .000 & .000 & & .000 & .000 & .000 \\
\hline & $\mathrm{N}$ & 45 & 45 & 45 & 45 & 45 & 45 \\
\hline \multirow[t]{3}{*}{$\mathrm{X} 4$} & $\begin{array}{l}\text { Pearson } \\
\text { Correlation }\end{array}$ & $.979^{* *}$ & $.972^{* *}$ & $.986^{* *}$ & 1 & $.979^{* *}$ & $.974^{* 4}$ \\
\hline & Sig. (2-tailed) & .000 & .000 & .000 & & .000 & .000 \\
\hline & $\mathrm{N}$ & 45 & 45 & 45 & 45 & 45 & 45 \\
\hline \multirow[t]{3}{*}{$\mathrm{X} 5$} & $\begin{array}{l}\text { Pearson } \\
\text { Correlation }\end{array}$ & $.981^{* *}$ & $.972^{* *}$ & $.971^{* *}$ & $.979^{* *}$ & 1 & $.986^{4 *}$ \\
\hline & Sig. (2-tailed) & .000 & .000 & .000 & .000 & & .000 \\
\hline & $\mathrm{N}$ & 45 & 45 & 45 & 45 & 45 & 45 \\
\hline \multirow[t]{3}{*}{$\mathrm{Y}$} & $\begin{array}{l}\text { Pearson } \\
\text { Correlation }\end{array}$ & $.978^{* *}$ & $.980^{* *}$ & $.960^{* *}$ & $.974^{* *}$ & $.986^{* 4}$ & 1 \\
\hline & Sig. (2-tailed) & .000 & .000 & .000 & .000 & .000 & \\
\hline & $\mathrm{N}$ & 45 & 45 & 45 & 45 & 45 & 45 \\
\hline
\end{tabular}

1. Hubungan Bukti Fisik (X1) Terhadap Kepuasan Konsumen (Y)

Hubungan Bukti fisik terhadap Kepuasan Konsumen (Y) diperoleh hasil sebesar 0,978 dengan signifikan sebesar $0.00<0.05$. Angka ini menunjukkan Bukti Fisik memilki korelasi yang cukup kuat yaitu sebesar 97,8\% terhadap Kepuasan Pelanggan.

2. Hubungan Kehandalan (X2) Terhadap Kepuasan Pelanggan (Y)

Hubungan Kehandalan terhadap terhadap Kepuasan Pelanggan sebesar 0,980 dengan signifikan sebesar $0.00<0.05$. Angka ini menunjukkan Kehandalan memilki korelasi yang cukup kuat yaitu sebesar 98,0 \% terhadap Kepuasan Pelanggan.

3. Hubungan Daya Tanggap (X3) Terhadap Kepuasan Pelanggan (Y)

Hubungan Daya Tanggap terhadap Kepuasan Pelanggan sebesar 0,960 dengan signifikan sebesar $0.000<0.05$. Angka ini menunjukkan kinerja Daya Tanggap memiliki korelasi yang cukup kuat yaitu sebesar 96,0 \% terhadap Kepuasan Pelanggan.

4. Hubungan Jaminan (X4) Terhadap Kepuasan Pelanggan (Y)

Hubungan Jaminan terhadap Kepuasan Pelanggan (Y) diperoleh hasil sebesar 0,974 dengan signifikan sebesar $0.00<0.05$. Angka ini menunjukkan Jaminan memilki korelasi yang cukup kuat yaitu sebesar 97,4 \% terhadap Kepuasan Pelanggan. 
5. Hubungan Empati (X5) Terhadap Kepuasan Pelanggan (Y)

Hubungan Empati terhadap terhadap Kepuasan Pelanggan sebesar 0,986 dengan signifikan sebesar $0.00<0.05$. Angka ini menunjukkan Empati memilki korelasi yang cukup kuat yaitu sebesar 98,6 \% terhadap Kepuasan Pelanggan.

\section{Analisis Regresi Linier Berganda}

Dengan menggunakan Statistical Package For Sosia Science (SPSS) 21.0 for Windows diperoleh hasil koefisien regresi sebagai berikut:

\section{Tabel 15 \\ Coefficients $^{\mathbf{a}}$}

\begin{tabular}{|c|c|c|c|c|c|c|}
\hline \multirow{2}{*}{\multicolumn{2}{|c|}{ Model }} & \multicolumn{2}{|c|}{$\begin{array}{l}\text { Unstandardized } \\
\text { Coefficients }\end{array}$} & \multirow{2}{*}{$\begin{array}{l}\text { Standardized } \\
\text { Coefficients } \\
\text { Beta }\end{array}$} & \multirow[b]{2}{*}{$\mathrm{t}$} & \multirow[b]{2}{*}{ Sig. } \\
\hline & & B & Std. Error & & & \\
\hline \multirow[t]{6}{*}{1} & (Constant) & -6.586 & 4.982 & & -1.322 & .194 \\
\hline & X1 & .024 & .111 & .030 & .216 & .830 \\
\hline & $\mathrm{X} 2$ & .331 & .096 & .396 & 3.434 & .001 \\
\hline & X3 & -.185 & .103 & -.239 & -1.801 & .079 \\
\hline & $\mathrm{X} 4$ & .160 & .133 & .199 & 1.204 & .236 \\
\hline & X5 & .488 & .102 & .609 & 4.761 & .000 \\
\hline
\end{tabular}

a. Dependent Variable: Y

Sumber Data : Output SPSS

berikut :

Dari tabel 15 di atas dapat diketahui model persamaan regresi linier berganda sebagai

$$
\begin{aligned}
& \mathrm{Y}=\alpha+\beta 1 \mathrm{X} 1+\beta 2 \mathrm{X} 2+\beta 3 \mathrm{X} 3+\beta 4 \mathrm{X} 4+\beta 5 \mathrm{X} 5+\varepsilon \text { atau } \\
& \mathrm{Y}=-6,586+0,024 \mathrm{X} 1+0.331 \mathrm{X} 2+-0,185 \mathrm{X} 3+0,160 \mathrm{X} 4+0.488 \mathrm{X} 5
\end{aligned}
$$

Persamaan diatas dapat dijelaskan sebagai berikut :

1. Konstanta sebesar - 6,586 artinya tidak ada kenaikan variabel Bukti Fisik (X1) Kehandalan (X2), Daya tanggap (X3), Jaminan (X4) dan Empati (X5) maka nilai Kepuasan Pelanggan (Y) sebesar - 6,586

2. Nilai koefisien regresi variabel Bukti fisik (X1) sebesar 0,0241 ini dapat diartikan bahwa setiap peningkatan variabel Bukti fisik sebesar 1, maka nilai Kepuasan pelanggan bernilai tetap (konstan)

3. Nilai Koefisiensi regresi variabel Kehandalan (X2) sebesar 0,331,artinya bahwa setiap peningkatan variabel Kehandalan sebesar 1, maka nilai Kepuasan pelanggan bernilai tetap (konstan)

4. Nilai Koefisien regresi variable Daya tanggap (X3) sebesar - 0,185, artinya tidak ada kenaikan variabel Daya tanggap maka nilai Kepuasan Pelanggan (X3) sebesar - 0,185

5. Nilai koefisien regresi variabel Jaminan (X4) sebesar 0,160 ini dapat diartikan bahwa setiap peningkatan variabel Jaminan sebesar 1, maka nilai Kepuasan Pelanggan bernilai tetap (konstan)

6. Nilai koefisiensi regresi variabel Empati (X5) sebesar 0,488,artinya bahwa setiap peningkatan variabel Empati sebesar 1, maka nilai Kepuasan Pelanggan bernilai tetap (konstan) 


\section{Pengujian Hipotesis}

1. Untuk mengetahui ada tidaknya pengaruh antara variabel Bukti fisik, Kehandalan, Daya tanggap, Jaminan dan Empati terhadap Kepuasan pelanggan secara parsial dan simultan dapat dilakukan dengan menggunakan hasil output SPSS sebagai berikut :

A. Uji Hipotesis Secara Parsial (uji t)

Untuk mengetahui variabel independen apakah berpengaruh secara signifikan atau tidak terhadap variabel dependen dapat dilakukan dengan membandingkan thitung dengan ttabel, jika thitung > ttabel maka dapat disimpulkan terdapat pengaruh antara variabel independen dengan variabel dependen atau sebaliknya jika thitung < tabel maka tidak terdapat pengaruh antara variabel independen terhadap variabel dependen.. Ttabel dapat dilihat pada tabel statistik pada signifikansi $0,05 / 2=0,025$ dengan derajat kebebasan $(\mathrm{df})=\mathrm{n}-\mathrm{k}-1=45-5-1=39$. Hasil yang diperoleh untuk ttabel sebesar 2,022, sedangkan thitung dapat dilihat dari hasil output SPSS pada tabel coefficient sebagai berikut :

Tabel 16

Coefficients $^{\mathrm{a}}$

\begin{tabular}{|c|c|c|c|c|c|c|}
\hline \multirow{2}{*}{\multicolumn{2}{|c|}{ Model }} & \multicolumn{2}{|c|}{$\begin{array}{l}\text { Unstandardized } \\
\text { Coefficients }\end{array}$} & \multirow{2}{*}{$\begin{array}{l}\text { Standardized } \\
\text { Coefficients } \\
\text { Beta }\end{array}$} & \multirow[b]{2}{*}{$\mathrm{t}$} & \multirow[b]{2}{*}{ Sig. } \\
\hline & & B & Std. Error & & & \\
\hline \multirow[t]{6}{*}{1} & (Constant) & -6.586 & 4.982 & & -1.322 & .194 \\
\hline & $\mathrm{X} 1$ & .024 & .111 & .030 & .216 & .830 \\
\hline & $\mathrm{X} 2$ & .331 & .096 & .396 & 3.434 & .001 \\
\hline & $\mathrm{X} 3$ & -.185 & .103 & -.239 & -1.801 & .079 \\
\hline & $\mathrm{X} 4$ & .160 & .133 & .199 & 1.204 & .236 \\
\hline & $\mathrm{X} 5$ & .488 & .102 & .609 & 4.761 & .000 \\
\hline
\end{tabular}

a. Dependent Variable: Y

Sumber Data : Output SPSS

Berdasarkan tabel di atas, selanjutnya penulis melakukan pengujian hipotesis secara parsial (uji t) masing-masing variabel penelitian yaitu sebagai berikut :

1. Bukti Fisik (X1) Terhadap Kepuasan Pelanggan (Y)

Hipotesis penelitian yang akan di uji adalah sebagai berikut:

Ho1 :Tidak terdapat pengaruh Bukti fisik terhadap Kepuasan pelanggan

Ha1 :Terdapat pengaruh Bukti fisik terhadap Kepuasan pelanggan

Pada tabel 16 coefficients diperoleh thitung variabel Bukti fisik sebesar 0,216 dengan tingkat signifikansi 0.830 , kemudian dibandingkan dengan ttabel sebesar 2.022 ternyata nilai thitung $(0,216)<2.022$, maka Ho di diterima dan Ha ditolak , artinya bahwa Bukti fisik tidak berpengaruh terhadap Kepuasan pelanggan.

2. Kehandalan (X2) Terhadap Kepuasan Pelanggan (Y)

Hipotesis penelitian yang akan di uji adalah sebagai berikut:

Ho1 :Tidak terdapat pengaruh Kehandalan terhadap Kepuasan pelanggan

Ha1 :Terdapat pengaruh Kehandalan terhadap Kepuasan pelanggan

Pada tabel 16 coefficients diperoleh thitung variabel Kehandalan sebesar 3.434 dengan tingkat signifikansi 0.001 kemudian dibandingkan dengan ttabel sebesar 2.022 ternyata 
nilai thitung (3.434) > 2.022, maka Ho di ditolak dan Ha diterima , artinya bahwa Kehandalan berpengaruh terhadap Kepuasan pelanggan.

3. Daya Tanggap (X3) Terhadap Kepuasan Pelanggan (Y)

Hipotesis penelitian yang akan di uji adalah sebagai berikut:

Ho1 :Tidak terdapat pengaruh Daya tanggap terhadap Kepuasan pelanggan

Ha1 :Terdapat pengaruh Daya tanggap terhadap Kepuasan pelanggan

Pada tabel 16 coefficients diperoleh thitung variabel Daya Tanggap sebesar -1.801 dengan tingkat signifikansi 0.079 kemudian dibandingkan dengan ttabel sebesar 2.022 ternyata nilai thitung $(-1.801)<2.022$, maka Ho diterima dan Ha ditolak, artinya bahwa Daya Tanggap tidak berpengaruh terhadap Kepuasan pelanggan.

4. Jaminan (X4) Terhadap Kepuasan Pelanggan (Y)

Hipotesis penelitian yang akan di uji adalah sebagai berikut:

Ho1 :Tidak terdapat pengaruh Jaminan terhadap Kepuasan pelanggan

Ha1 :Terdapat pengaruh Jaminann terhadap Kepuasan pelanggan

Pada tabel 16 coefficients diperoleh thitung variabel Jaminan sebesar 1.204 dengan tingkat signifikansi 0.236 kemudian dibandingkan dengan ttabel sebesar 2.022 ternyata nilai thitung $(1.204)<2.022$, maka Ho diterima dan Ha ditolak, artinya bahwa Jaminan tidak berpengaruh terhadap Kepuasan pelanggan.

5. Empati (X5) Terhadap Kepuasan Pelanggan (Y)

Hipotesis penelitian yang akan di uji adalah sebagai berikut:

Ho1 :Tidak terdapat pengaruh Empati terhadap Kepuasan pelanggan

Ha1 :Terdapat pengaruh Empati terhadap Kepuasan pelanggan

Pada tabel 16 coefficients diperoleh thitung variabel Empati sebesar 4.761 dengan tingkat signifikansi 0.000 kemudian dibandingkan dengan ttabel sebesar 2.022 ternyata nilai thitung (4.761) > 2.022, maka Ho ditolak dan Ha diterima, artinya bahwa Empati berpengaruh terhadap Kepuasan pelanggan.

6. Uji Hipotesis Secara Simultan (Uji F)

Uji $\mathrm{F}$ digunakan untuk mengetahui ada tidaknya pengaruh secara bersama sama (simultan) variabel bebas yaitu Bukti Fisik (X1), Kehandalan (X2), Daya tanggap (X3), Jaminan (X4) dan Empati (X5) terhadap variabel terikat, Kepuasan Konsumen (Y). Uji $\mathrm{F}$ dilakukan dengan cara membandingkan $F_{\text {hitung }}>F_{\text {tabel }}$ dimana $F_{\text {hitung }}$ diperoleh dari hasil Output SPSS dalam Anova, sedangkan $\mathrm{F}_{\text {tabel }}$ diperoleh dari tabel Df penyebut $=\mathrm{N}$ $\mathrm{k}-1=45-5-1=39$, df pembilang-k-5, yaitu $\mathrm{F}_{\text {tabel }}=2.460$ Hasil Output SPSS untuk $\mathrm{F}_{\text {hitung }}$ di sajikan pada Tabel 17

Tabel 17

ANOVA $^{\mathrm{a}}$

\begin{tabular}{|l|l|l|l|l|l|}
\hline Model & $\begin{array}{l}\text { Sum } \\
\text { Squares }\end{array}$ & df & Mean Square & F & Sig. \\
\hline Regression & 86980.321 & 5 & 17396.064 & 425.265 & $.000^{b}$ \\
Residual & 1595.351 & 39 & 40.906 & & \\
Total & 88575.672 & 44 & & & \\
\hline
\end{tabular}

a. Dependent Variable: $Y_{-}$total

b. Predictors: (Constant), X5_total, X4_total, X3_total, X2_total, X1_total

Sumber Data : Output SPS 
Berdasarkan output hasil pengujian SPSS 21,0 dapat disimpulkan bahwa hasil $\mathrm{F}_{\text {hitung }}$ sebesar 425.265 dengan tingkat tingkat signifikansi 0,000, artinya $F_{\text {hitung }}$ Sebesar $425.265>F_{\text {tabel }}$ 2.460 dengan batas signifikan 0.05, nilai signifikan berada di bawah taraf 5\%, yang berarti Ho ditolak dan Ha diterima, sehingga terbuktibahwa Bukti Fisik, Kehandalan, Daya Tanggap, Jaminan dan Empati memiliki pengaruh yang signifikan dan memiliki nilai positif terhadap Kepuasan Pelanggan secara Simultan.

\section{Uji Adjust $\mathbf{R}^{2}$ (Koefisien Determinasi)}

Koefisien determinasi bertujuan untuk mengukur seberapa jauh kemampuan model dapat menjelaskan variasi variabel dependen. Nilai $R^{2}$ mempunyai interval antara 0 sampai $1(0 \leq$ $\mathrm{R}^{2} \leq 1$ ). Jika nilai $\mathrm{R}^{2}$ bernilai besar (mendekati 1 ) berarti hampir semua variabel bebas dapat memberikan informasi yang dibutuhkan untuk memprediksi variabel dependen. Sedangkan Adjusted $\mathrm{R}^{2}$ bernilai kecil berarti kemampuan variabel bebas dalam menjelaskan variabel dependen sangat terbatas.(Ghozali,2013:97) Koefisien determinasi adalah kuadrat dari nilai korelasi pada tabel Model Summary Output SPSS yang dapat dihasilkan adalah sebagai berikut :

\section{Tabel 18}

\begin{tabular}{|c|c|c|c|c|c|c|}
\hline \multicolumn{7}{|c|}{ Model Summary ${ }^{b}$} \\
\hline \multirow{2}{*}{$\begin{array}{l}\text { Mode } \\
1\end{array}$} & \multirow[b]{2}{*}{$\mathrm{R}$} & \multirow[b]{2}{*}{ R Square } & \multirow{2}{*}{$\begin{array}{l}\text { Adjustec } \\
\text { Square }\end{array}$} & \multirow{2}{*}{$\mathrm{R}$} & \multirow{2}{*}{$\begin{array}{l}\text { Std. Error of } \\
\text { the Estimate }\end{array}$} & $\begin{array}{l}\text { Durbin- } \\
\text { Watson } \\
\end{array}$ \\
\hline & & & & & & Sig. F Change \\
\hline 1 & $.991^{\mathrm{a}}$ & .982 & .980 & & 6.39581 & .000 \\
\hline
\end{tabular}

a. Predictors: (Constant), X5, X4, X3, X2, X1

b. Dependent Variable: Y

Dari tabel 18 dapat diketahui bahwa variable-variabel independen yang meliputi Bukti Fisik, Kehandalan, Daya Tanggap, Jaminan dan Empati mempengaruhi Kepuasan Pelanggan sebesar $98 \%$, sedangkan sisanya sebesar $2 \%$ dipengaruhi oleh faktor lain diluar model penelitian.

\section{PENUTUP}

\section{Kesimpulan}

Berdasarkan hasil penelitian pembahasan mengenai Pengaruh Kualitas Pelayanan terhadap Kepuasaan Pelanggan KRL Commuterline di Kebayoran Lama

1. Bukti Fisik tidak memiliki pengaruh yang signifikan terhadap Kepuasan Pelanggan dengan tingkat signifikan sebesar $0.830>0,05$ atau thitung < ttabel yaitu sebesar $0.216<$ 2.022. Artinya pihak manajemen kereta api harus memperhatikan variabel Buktifisik, seperti: fasilitas pelayanan, kapasitas tempat duduk, kebersihan kereta, penampila petugas, tersedianya info pelayan rute perjalanan karena variabel ini dirasakan kurang maksimal oleh responden.

2. Kehandalan memiliki pengaruh yang signifikan terhadap Kepuasan Pelanggan dengan tingkat signifikan sebesar $0.001<0,05$ atau thitung >ttabel yaitu sebesar $3.434>2.022$. Artinya pihak manajemen kereta api harus mempertahankan bahkan meningkatkan kualitas pelayanan khususnya Kehandalan untuk mempertahankan kepuasaan pelanggan. 
3. Daya tanggap tidak memiliki pengaruh yang signifikan terhadap Kepuasan Pelanggan dengan tingkat signifikan sebesar $0.079>0,05$ atau thitung < ttabel yaitu sebesar $-1.801<$ 2.022. Artinya pihak manajemen kereta api harus harus memperhatikan variabel Daya tanggap , seperti: kecepatan petugas merespon keluhan, petugas tanggap melayani konsumen, kecepatan petugas mengenai permintan konsumen, petugas melakukan tindakan secara tepat dan cepat karena variabel ini dirasakan kurang maksimal oleh responden.

4. Jaminan tidak memiliki pengaruh yang signifikan terhadap Kepuasan Pelanggan dengan tingkat signifikan sebesar $0.236>0,05$ atau thitung < ttabel yaitu sebesar $-1.204<2.022$. Artinya pihak manajemen kereta api harus harus memperhatikan variabel Jaminan, seperti: pengetahuan petugas mengenai produk commuterline, kemampuan petugas dalam menjalankan pekerjaannya, keramahan petugas dalam memberikan pelayanan, kesopanan petugas dalam melayani karena variabel ini dirasakan kurang maksimal oleh responden.

5. Empati memiliki pengaruh yang signifikan terhadap Kepuasan Pelanggan dengan tingkat signifikan sebesar $0.000<0,05$ atau thitung $>$ ttabel yaitu sebesar $4.761>2.022$. Artinya pihak manajemen kereta api harus mempertahankan bahkan meningkatkan kualitas pelayanan khususnya Empati untuk mempertahankan kepuasaan pelanggan.

6. Hasil penelitian menunjukkan bahwa Bukti Fisik, Kehandalan, Daya Tanggap, Jaminan dan Empati secara bersama sama memiliki pengaruh yang signifikan terhadap Kepuasan Pelanggan dengan tingkat signifikan sebesar $0.000<0,05$ atau $F_{\text {hitung }}>F_{\text {tabel }}$ yaitu sebesar $425.265>2.460$. artinya terdapat pengaruh Korelasi kuat bahwa Bukti Fisik, Kehandalan, Daya Tanggap, Jaminan dan Empati mempengaruhi Kepuasan Pelanggan sebesar 98 \%, sedangkan sisanya sebesar $2 \%$ dipengaruhi oleh faktor lain diluar model penelitian.

\section{DAFTAR PUSTAKA}

Ahmad Suharto (2014),“Analisis Dimensi Kualitas pelayanan Terhadap Kepuasan Pelanggan pada Laboratorium Parahita Diagnostic Center Cabang Jember" .JurnalISSN: 1412-5366

Basuki Rahmat (2013), "Pengaruh Kualitas Layanan terhadap Kepuasan Konsumen pada layanan Drive Thru McDonald's". JURNAL MANAJEMEN PEMASARAN

Vol.1, No.1, (1-12)

Fandy Tjiptono, 2011. Pemasaran Jasa. Yogyakarta : Penerbit Bayu Media Publishing

Fandy Tjiptono, 2012. Service Manegement Mewujudkan Layanan prima. Yogyakarta : Penerbit C.V ANDI OFFSET.

Fandy Tjiptono, 2014. Pemasaran Jasa, Prinsip, Penerapan dan Penelitian. Yogyakarta : Penerbit C.V ANDI OFFSET.

Husein, 2013. Metodelogi Penelitian Untuk Skripsi dan Tesis Bisnis. PT. Raja Grafindo Persada, Jakarta

Imroatul Khasanah (2010), "Analisis Pengaruh Kualitas Pelayanan terhadap Kepuasan

Konsumen RS.St.Elisabeth Semarang”. Aset, Februari 2010, hal. 117-124 Vol. 12 No. 2.ISSN 1693-928X

Lovelock Christopher. 2010. Pemasaran Jasa. Erlangga. Jakarta

Lupiyoadi Rambat. 2012. Manajemen Pemasaran Dasar. Salemba Empat. Jakarta

Philip Kotler, Kevin Lane keller, 2009. Ahli Bahasa : Benyamin Molan. Manajemen pemasaran. Edisi 12 Jilid 1 \& 2 Cetakan Keempat. Jakarta : PT Indeks. 
Philip Kotler, Kevin Lane keller, 2012. Manajemen pemasaran Edisi 13 Jilid 1 \& 2. Jakarta :

Penerbit Erlangga

Priyanto Dwi. (2012)Belajar Cepat Olah Data Statistik dengan SPSS. Penerbit ANDI. Yo

Nur Hayati (2011),"Pengaruh Kualitas Layanan terhadap kepuasan pelanggan pada konsumenKereta Api Kelas Eksekutif Turangga". Jurnal Sains Manajemen \& Akuntansi Vol. III No. 2/November/2011

Sugiyono. ( 2012) Metode Penelitian Kuantitatif Kualitatif dan R\&D. Penerbit Alfabeta 